\title{
ORUŽANE AKCIJE KOMUNISTIČKIH ILEGALACA U BEOGRADU TOKOM 1942.
}

\begin{abstract}
APSTRAKT: U članku se razmatraju oružane akcije beogradskih komunista koje su izvedene u 1942. godini. Dat je i kratak prikaz organizacione strukture, kadrova i materijalnih resursa KPJ, oružane sile i mera okupatora i kolaboracionista u Beogradu. Rad je napisan na osnovu arhivske grade, periodike i relevantne literature.
\end{abstract}

Ključne reči; Srbija, Beograd, Drugi svetski rat, okupacija, kolaboracionisti, KPJ, komunistički ilegalci, likvidacije

Napad Nemačke na SSSR 22. juna 1941. iz korena je izmenio odnos okupator-komunisti na teritoriji okupirane Srbije. Policijske i obaveštajne strukture okupatora i kolaboracionista od ovog perioda kao jedan od glavnih pravaca delovanja imaju hapšenje komunista i suzbijanje njihove delatnosti. Komunistička partija Jugoslavije (KPJ) menja dotadašnji stav prema ratu u toku kao „imperijalističkom“, posle niza direktiva od strane Kominterne formuliše novu političku platformu čija je suština bila okupljanje svih snaga spremnih za borbu protiv okupatora pod vođstvom komunista i otpočinje oružanu borbu. Beogradski komunisti pod ovakvom platformom izvršavaju najrazličitije akcije od paljenja motornih vozila, garaža, novina, atentata do pisanja i lepljenja parola, sa ciljem dizanja otvorenog ustanka. Represija okupatora je naterala KPJ u Beogradu da od jeseni 1941. promeni oblik borbe. Nov model pronađen je u izvršavanju atentata na okupatorske i kolaboracionističke organe i zvaničnike i poverenike policije. Krajem oktobra izvode se poslednji atentati i KPJ usled teške situacije prouzrokovane merama i represijom okupatora od ovog perioda do kraja 1941. nije $u$ stanju da ponovo pokrene borbu u Beogradu. ${ }^{1}$

${ }^{1}$ Više o akcijama beogradskih komunista tokom 1941: Beograd u ratu i revoluciji 1941-1945, knj. 1, Beograd 1984; Rade Ristanović, Likvidacije kao jedan od oblika borbe komunističkih ilegalaca u Beogradu tokom 1941. godine, Vojnoistorijski glasnik, br. 2, Beograd 2011, 50-71. 


\section{Organizaciona struktura KPJ, udarne grupe, kadrovski i materijalni resursi}

Plan KPJ iz decembra 1941. da se na teritoriju okupirane Srbije upute jače snage radi proširenja slobodne teritorije doživeo je potpun neuspeh usled lošeg poznavanja situacije u Srbiji. ${ }^{2}$ Komunističko rukovodstvo u Srbiji ostalo je izolovano i prepušteno samo sebi. Uprkos direktivi Centralnog komiteta KPJ da se članovi Pokrajinskog komiteta (PK) spoje i "tako obezbede jedinstvo rukovodstva" do toga nije došlo jer se Blagoje Nešković, sekretar ovog organa, nalazio u Beogradu, a ostali članovi bili su na teritoriji južne i zapadne Srbije. ${ }^{3}$ Nešković, duboko ukopan u Beogradu, vodio je sam komunističku organizaciju u Srbiji. ${ }^{4}$

I reorganizacija koja se $u$ to vreme odvijala $u$ beogradskoj organizaciji nosila je Neškovićev pečat. Formiran je Mesni komitet (MK) u sastavu: Jelena Ćetković, sekretar i Petar Ristić, Stevan Jovičić, Bora Drenovac, članovi. Novoformirani MK je preko sekretara bio povezan sa Okružnim komitetom (OK), od koga je primao direktive. Po dolasku okupatora KPJ je u Beogradu sa strukovne prešla na teritorijalnu podelu. Teritorija Uprave grada Beograda (UGB) podeljena je na sedam partijskih i sedam skojevskih rejona. Svaki od rejona imao je svoje rukovodstvo koje je preko jednog od članova bilo povezano sa MK. Novoformirani MK postavio je i rukovodstva za svih sedam partijskih rejona. U skojevskoj organizaciji nije bilo kadrovskih promena. Mesni komitet SKOJ-a, koji je obrazovan u oktobru 1941. u sastavu Bora Drenovac, sekretar i članovi Josip Šćurla, Dragutin Filipović, Branislav Krstić i Branko Mišković, nastavio je rad i početkom 1942.

Za razliku od 1941. godine, kada je glavni pravac delovanja bio borba protiv okupatora, prema svedočenju Blagoja Neškovića rad beogradskih komunista $\mathrm{u}$ ovom periodu uglavnom se manifestovao kroz prihvatanja preživelih boraca i vršenje „priprema za obnovu ustanka“. ${ }^{5}$ Ovo nije značilo da je KPJ odustala od ambicije da vodi borbu protiv okupatora i kolaboracionista u Beogradu. Direktiva od jeseni 1941. da se prikupljaju adrese vodećih ljudi okupacionog i kolaboracionističkog režima, prati njihovo kretanje "radi određivanja načina na koji će se ovi likvidirati“ forsirana je i od strane novoformiranog MK. ${ }^{6}$

Svi rejonski aktivi dobijaju naređenje da formiraju tzv. udarne grupe. Zamišljeno je da se ove jedinice sastoje od dva do četiri člana, sa zadat-

\footnotetext{
${ }^{2}$ Branko Petranović, Srbija u Drugom svetskom ratu, Beograd 1992, 321.

${ }^{3}$ Venceslav Glišić, Komunistička partija Jugoslavije u Srbiji, Beograd 1975, 100.

${ }^{4}$ B. Petranović, Srbija u Drugom svetskom ratu, 314.

${ }^{5}$ Istorijski arhiv Beograda (IAB), Legat Blagoja Neškovića (LBN), k. 15.

${ }^{6}$ IAB, Uprava grada Beograda (UGB), Specijalna policija (SP), IV-156.
} 
kom da vrše likvidacije i razoružavaju nemačke i kolaboracionističke vojnike. Direktiva kojom se naređuje likvidacija dolazila je od MK KPJ i bez znanja ovog foruma svaka akcija bila je zabranjena. ${ }^{7}$ Detalji u vezi sa izvođenjem akcije bili su dostupni samo onima koji neposredno učestvuju u njenoj organizaciji i sprovođenju, a po izvršenju, bilo je strogo zabranjeno da se informacije prenose ostalim članovima organizacije. Sama realizacija poveravana je rejonskom aktivu na čijoj teritoriji je trebalo da bude izvedena likvidacija. U slučaju da taj rejon nema udarnu grupu, onda je izvršenje prepuštano nekom drugom rejonu. KPJ je izdala direktivu svim aktivima da se prikupe adrese i prati kretanje zvaničnika okupacionog i kolaboracionističkog režima. Ovi zadaci su, osim komunistima, poveravani i simpatizerima. Po prikupljenim informacijama, stvorili bi se uslovi za izvođenje akcije. Sam napad vršilo je dvoje do četvoro ljudi, sa prethodno utvrđenim zadacima. Obično je jedno do dva lica bilo zaduženo da puca u metu, dok su ostali štitili odstupnicu. Postojali su i ljudi određeni da neposredno posle sprovođenja plana prođu mestom događaja i izveste o rezultatima. ${ }^{8}$

Beogradska organizacija je u 1942. godinu ušla kadrovski desetkovana. Glavni razlog bila su hapšenja komunista koja su dostigla zenit u septembarskoj provali kada je uhapšen celokupan MK KPJ i gotovo celokupan MK SKOJ-a (hapšenje je izbegao samo Marko Nikezić). Početkom 1942. godine KPJ je u Beogradu imala na raspolaganju oko 234 člana KPJ i oko 500 članova SKOJ-a. ${ }^{9}$ Naše istraživanje rađeno na uzorku od 200 članova KPJ i SKOJ-a pokazalo je da je prosečna starost beogradskih komunista bila oko 23 godine, da je samo nešto više od jedne četvrtine prošlo osnovnu vojnu obuku i da je većina dolazila iz redova radnika, studenata i đaka. ${ }^{10}$

Ono što je delilo ovu grupu mladih radnika, studenata i đaka od njihovih vršnjaka i kolega i predstavljalo odlučujući faktor da se pojedini od njih transformišu u atentatore, bila je ideologija oko koje su bili okupljeni. Komunističku ideologiju možemo svrstati u red agresivnih ideologija, kojima je, kao što je Jovan Rašković govorio, osnovni sadržaj „redukcija i rotacija svjesti“ pojedinca "na sadržaje korisne za ideologiju“. ${ }^{11}$ Navedena teza

${ }^{7}$ IAB, UGB, SP, IV-156/6.

${ }^{8} \mathrm{IAB}, \mathrm{UGB}, \mathrm{SP}, \mathrm{IV}-30$.

${ }^{9}$ Đurđević Čedomir, Komunistička partija Jugoslavije - organizator i nosilac NOP-a u Beogradu 1941-1944, Beograd u ratu i revoluciji 1941-1944, ur. Gojko Lađević, Beograd 1971, 16-36.

${ }^{10}$ Istraživanje je rađeno metodom slučajnog uzorka na broju od 200 komunističkih ilegalaca. Podaci su uzimani iz dosijea ilegalaca koje su agenti Odeljenja Specijalne policije uhapsili u periodu od juna 1941. do marta 1942: IAB, UGB, SP, k. 162, k. 164, k. 169, k. 180, k. 181 , k. 216, k. 301, k. 432, k. 580, k. 338, k. 300, k. 397, k. 398, k. 422, k. 363, k. 357, k. 346 , k. 335, k. 309, k. 336, k. 337, k. 338.

${ }^{11}$ Citirano prema: Radomir Smiljanić, Prevod, polemički komentari i razmatranja knjige Majn Kampf Adolfa Hitlera, Zrenjanin 2001, 516. 
dobija najbolju potvrdu kada ukažemo na zahteve čijem ispunjenju je u predratnom periodu svaki pojedinac morao težiti ukoliko je želeo da bude deo komunističkog pokreta.

1. Besprekornost $\mathbf{u}$ ličnom životu. Komunisti nisu delili politički rad člana partije od njegovog ličnog života, jer se smatralo da je to prvi korak ka dobijanju poverenja masa. KPJ je nadzirala privatne živote svojih članova i niko nije mogao da bude primljen a da se prvo ne proveri njegov „lični život". Za osobine kao što su neverstvo, sebičnost, izbirljivost u hrani, preterano odavanje alkoholu i ostale mane kojima su komunisti pripisivali „buržoasko“ poreklo nije bilo mesta u karakteru „novog čoveka“ pa je svaka njihova pojava oštro osuđivana. ${ }^{12}$

2. Boljševička skromnost. Ovo je u najužem smislu značilo da svaki komunista mora biti „svjestan toga da je on samo vojnik radničke klase i da bude spreman sve što treba izvršiti sve štogod mu partija naredi." Karijeristima i nezdravim ambicijama nije bilo mesta $u$ „Komunističkoj partiji, jer to su svojstva koja sa uspjehom iskorištava klasni neprijatelj.“" ${ }^{13}$

3. Rad u masama, jer „partija mora biti kovačnica rukovoditelja masa, ljudi koji će znati učiti mase, te rukovoditi njenim organizacijama i borbom i da je najbolja legitimacija za ulaz u partiju škola koju je prošao kandidat na radu u masovnim organizacijama." KPJ je u predratnom periodu osuđivala pasivnost i tražila od svojih aktivista „da budu stalno u akciji tj. da bez prestanka rade među zaposlenim i besposlenim radnicima, među sirotinjom među seljacima da pripremaju i organizuju njihovu borbu." Zaustavljanje rada usled partijskih provala, teške situacije, čekanje novih uputa, direktiva i novog rukovodstva smatralo se „likvidatorstvom“, tražilo se orijentisanje na sopstvene snage. ${ }^{14}$

4. Gvozdena disciplina jer, „armija koja nema disciplinu biva bezuvjetno pobjeđena od neprijatelja. Za avangardu radničke klase ovo pravilo još više važi, jer mora da se bori sa jače naoružanim neprijateljem. Bez gvozdene discipline i unutarnje povezanosti Komunistička partija ne može pobjediti.“ Ukazivalo se da nedisciplina „stvara pomutnju u partijskim redovima i služi direktno klasnom neprijatelju“, onemogućava „sprovođenje partijske linije, ona ruši jedinstvo volje i paralizira razvitak partije. ${ }^{15}$

${ }^{12}$ Koliko se daleko išlo, najbolje svedoči anegdota koju je preneo Milovan Đilas. Jedan od čelnih ljudi KPJ Edvard Kardelj prilikom posete kolhozu u SSSR-u nije hteo da jede trulo meso koje mi je servirano. Kako ga je Spasenija Babović optužila pred KPJ i Kominternom za buržoasko ponašanje, Kardelju nije preostalo ništa drugo nego da prizna „grešku“. - Milovan Đilas, Memoir of a revolutinary, New York 1973, 317; Proleter, br. 1, 1933, maj, 6 .

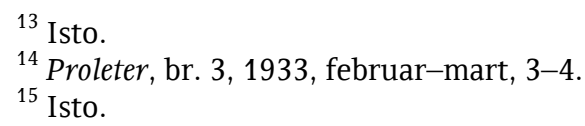


5. Budnost jer, „danas kada sa svija strana neprijatelj naše partije i radničke klase pokušava da pomoću svojih agenata razbija jedinstvo naše partije potrebno je da svi članovi partije svojom budnošću prema svim skretanjima čuvaju jedinstvo partije. Treba se odlučno boriti protiv svih zastranjivanja i unošenja bilo kakvog razdora u partiju."

6. Zahtevalo se „izučavanje“ Marksa, Engelsa, Lenjina, Staljina, budući da je to bilo „najjače oružje kojim se radnička klasa služi u svojoj borbi“ i od njega zavisi „uspjeh borbe radničke klase.“" ${ }^{16}$ Razvijanje makrsističko-lenjinističke svesti išlo je u prvoj liniji preko proučavanja marksističko-lenjinističke literature. Svi aktivisti su bili dužni da čitaju knjige i novine koje je izdavala KPJ, a zatim da o njihovoj sadržini diskutuju na sastancima i pokušaju da primene zaključke u svojoj organizaciji.

7. Konspirativnost. $\mathrm{Na}$ osnovu raspodele rada svako je trebalo da „vrši svoj posao" i da o tome nikome ne priča. Onaj član koji je „suviše ljubopitljiv i bude se raspitivao za sve poslove koji se obavljaju u organizaciji, a za koje nije on nadležan da zna treba da izazove sumnju i proverku da nije slučajno tajni agent-provokator." ${ }^{17}$ Svi komunisti bili su u obavezi da umesto pravih imena koriste pseudonime i da ih često menjaju. Nisu smeli da privlače pažnju svojom fizičkom pojavom. Trebalo je izbegavati zapisivanje, a ako je to neophodno, onda je to moralo biti šifrovano. Zabranjeno je bilo održavati sastanke u stanovima gde žive komunisti ili na mestima koja su poznata policiji. ${ }^{18}$ Trebalo je izučavati metode rada policije, upoznavati policijske kadrove i mesta gde se nalaze agenti. ${ }^{19}$

8. Pravilno držanje pred „klasnim neprijateljem“. ${ }^{20}$ Još u predratnom periodu najstrože je bilo zabranjeno pred policijom govoriti „o ljudima koji rade u organizaciji, materijalu, adresama, stanovima itd." Lična odbrana, „spasavanje samog sebe, trebalo je da bude sporedna stvar." Glavno i osnovno pravilo bilo je „nastojati da se ništa ne otkrije policiji, da se ne kompromituju drugovi, da se svojim iskazom ne potvrđuje ni ono, što policija već zna ili se pravi da zna." Bolje je, kako je isticano, biti ubijen „nego poći na kompromis sa žandarmskom čizmom i provaljivati organizaciju i pojedine drugove. Bolje je poginuti kao mučenik sa čisto komunističkom svešću nego dobiti 15 ili 20 godina zajedno sa prijavom ili neizbrisivom mrljom, koja je često istovetna sa otvorenim izdajstvom. ${ }^{21}$ KPJ je u predratnom periodu savetovala da se prema saradnicima policije "stvori bedem prezira i bojkota“, ali je pod okupacijom ovaj stav radikalno izmenjen. Od

\footnotetext{
${ }^{16}$ Isto, 7.

${ }^{17}$ Proleter, br. 15, 1930, januar, 4-5.

18 Isto.

${ }^{19}$ Proleter, br. 2, 1933, februar, 3-4.

${ }^{20}$ Proleter, br. 10, 1930, januar, 2.

${ }^{21}$ Isto.
} 
leta 1941. KPJ je organizovala niz atentata na lica za koja se sumnjalo da su sarađivala sa okupatorom.

Svaka udarna grupa imala je zadatak da prikupi sopstveni „arsenal“ oružja, za koji bi bio odgovoran jedan od članova. ${ }^{22}$ Nemamo podatke koliko je ovakvih skladišta bilo u Beogradu. Prema sećanju Blagoja Neškovića oružja je bilo malo, naročito lakog streljačkog naoružanja, koje se većinom pokazivalo nepouzdano, usled starosti i lošeg održavanja. ${ }^{23}$ Pred likvidaciju, dužnost sekretara rejona bila je da naloži pripremu oružja iz magacina, a njega je obično preuzimalo lice koje ne učestvuje u samoj likvidaciji. Primopredaja se vršila po strogo konspirativnim pravilima. Lice određeno za ovaj zadatak nije obaveštavano šta nosi i za koje potrebe, već je samo dobijalo osnovne informacije, poput lozinke i adrese na koju treba da se javi. ${ }^{24}$ Oružje je prenošeno u korpama, među drvima za potpalu, metalnim kantama ili kamuflirano na drugi način. Sekretar bi članovima udarne grupe podelio oružje pred samu akciju ili dan pre. Po izvršenju, istim postupkom, oružje je vraćano $u$ arsenal. U slučaju da udarna grupa nije raspolagala naoružanjem, viša veza ga je obezbeđivala i predavala rejonskom sekretaru. ${ }^{25}$

\section{Oružana sila i mere okupatora i kolaboracionista}

Od 22. juna 1941. komunisti se nalaze na udaru policijskih i obaveštajnih struktura okupatora i kolaboracionista na teritoriji Srbije. Najopasniji neprijatelji beogradskih komunista bili su organi IV antikomunističkog odseka Odeljenja specijalne policije. ${ }^{26} \mathrm{~S}$ obzirom na njihovo predratno iskustvo nećemo pogrešiti ako kažemo da su Božidar Bećarević, šef ovog odseka i njegove kolege bili najbolji poznavaoci organizacione strukture, oblika delovanja i kadrova KPJ na teritoriji Beograda. Više od svega govore rezultati njihovog rada izneti u izveštaju Odeljenja specijalne policije za 1941. godinu, u kome se navodi da je kroz zatvor UGB prošlo 2.975 lica „po raznim političko-defetističko komunističkim deliktima“, a od ovog broja upućeno je u logor 510 lica. ${ }^{27}$ Odsek je imao i terensku službu. Agenti raspoređeni na ovu dužnost kružili bi automobilom ili šetali ulicama Beograda

${ }^{22}$ Jedno od skrovišta naoružanja KPJ nalazilo se na Zelenom vencu br. 5. „Arsenal“ na Zelenom vencu pripadao je III partijskom rejonu, a za njega je bio zadužen Jure Čula. - J. Čule, Ilegalno skladište oružja u okupiranom Beogradu, Godišnjak grada Beograda, knj. 8, Beograd 1961, 186.

${ }_{23}^{2}$ IAB, Memoarska građa-27 (MG), sećanja Blagoja Neškovića, 36, 57.

24 Isto.

${ }^{25}$ IAB, UGB, SP, IV-196/83.

${ }^{26}$ Više o ovoj temi: Branislav Božović, Specijalna policija u Beogradu 1941-1944, Beograd 2003.

${ }^{27} \mathrm{IAB}, \mathrm{UGB}, \mathrm{SP}, \mathrm{IV}-107$. 
i tražili poznate komuniste. ${ }^{28}$ Od ukupnog broja izvedenih atentata u 1941, službenici IV odseka našli su se najviše puta na meti komunističkih ilegalaca. ${ }^{29}$ Osim kolaboracionista i delovi nemačkog policijskog aparata bili su usmereni ka suzbijanju organizacije KPJ u Beogradu. Odeljenje IV-a Gestapoa, na čijem čelu se nalazio Erik Vineke (Erich Wienecke), bilo je zaduženo za suzbijanje komunizma i marksističkog pokreta. ${ }^{30}$

Beograd je bio centar okupacione i kolaboracionističke uprave i značajno saobraćajno čvorište, čime je održavanje reda i mira u gradu bilo od izuzetnog značaja za zagovornike politike "novog svetskog poretka“. Feldkomandantura 599 predstavljala je oblasnu komandu koja je na teritoriji beogradskog okruga vršila nadzor nad svim objektima i kontrolu gradske teritorije. Radi lakšeg patroliranja i čuvanja raznih objekata, teritorija UGB je podeljena na sedam stražarskih odseka (Wacherviere). Svaki odsek bio je potčinjen komandi odseka (Abshnitskommand). Za osiguranje teritorije Beograda bila je zadužena 704. pešadijska divizija, čiji je jedan puk upotrebljen za njegovo stražarsko obezbeđenje. ${ }^{31} \mathrm{U}$ zavisnosti od veličine teritorije koju kontroliše i broja objekata koji obezbeđuje, svaki odsek je imao na raspolaganju do dve pešadijske čete. Ostatak jedinica sačinjavale su kasarnu, rezervu Operativnog štaba straže (Einsatzstab Wache) spremnog u svakom trenutku da reaguje u slučaju potrebe. ${ }^{32}$ Funkciju područnih organa vršilo je i 16 kvartova i dva policijska komesarijata železničke i parobrodarske policije UGB. ${ }^{33}$

Od 6. maja 1941. ponovo je uspostavljena žandarmerija, koja od tog perioda predstavlja organ državnih vlasti zadužen za javnu bezbednost $\mathrm{u}$ gradovima i unutrašnjosti. Žandarmerija je ukinuta u martu 1942. kada dolazi do formiranja Srpske državne straže (SDS). ${ }^{34}$ Obrazovana je Komanda srpske državne straže UGB koja do 3. aprila dostiže ukupnu jačinu od 50 oficira i 1.247 vojnika. ${ }^{35} \mathrm{U}$ Beogradu su bile smeštene i brojne okupacione i kolaboracionističke organizacije, ustanove i uprave koje nisu vršile policij-

\footnotetext{
${ }^{28}$ IAB, UGB, SP, IV-177.

${ }^{29}$ Rade Ristanović, Likvidacije kao jedan od oblika borbe..., 68.

${ }^{30}$ Nemačka obaveštajna služba, knj. IV, Beograd 1959, 418.

${ }^{31}$ Više o ovoj temi: Muharem Kreso, Njemačka okupaciona uprava u Beogradu 19411944, Beograd 1979.

${ }^{32}$ Isto, 87.

${ }^{33}$ B. Božović, Specijalna policija u Beogradu 1941-1944, 30.

${ }^{34}$ Posle opsežnih priprema i razgovora vođenih uglavnom na relaciji Majsner-Nedić, 3. marta obrazovana je Srpska državna straža (SDS) sa zadatkom da vrši policijsku i graničnu službu na teritoriji Srbije. Formiranje SDS-a predstavljalo je objedinjavanje oružane sile koja se nalazila pod direktnom komandom Nedićeve vlade. SDS se sastojao od gradske, poljske i granične straže, a na njegovom čelu je stajao komandant. Više o formiranju i radu SDS u: Bojan Dimitrijević, Vojska Nedićeve Srbije: oružane snage srpske vlade 1941-1945, Beograd 2011.

${ }^{35}$ B. Dimitrijević, Vojska Nedićeve Srbije..., 177.
} 
sku vlast na teritoriji UGB-a, ali su njihovi pripadnici svojim prisustvom uvećavali broj naoružanih ljudi na njegovim ulicama i sami tim otežavali izvođenje akcija.

Mere koje su okupator i kolaboracionisti sprovodili u nameri da spreče izvođenje akcija, ali i da parališu rad KPJ u Beogradu, mogu se podeliti u dve grupe. Prvoj pripadaju represivne mere. Organi policije hapsili su sve one za koje su sumnjali da pripadaju ili pomažu KPJ u Beogradu. Jula 1941. formiran je logor na Banjici gde su zatvarani uhapšeni komunisti, njihove porodice, simpatizeri. Nacisti su kao jedan od metoda u suzbijanju svake građanske neposlušnosti primenjivali i načelo kolektivne odgovornosti. Isti metod korišćen je u obračunu sa komunističkim pokretom. Streljanje 16 komunista i Jevreja u Beogradu, Javno pogubljenje komunističkih terorista u Beogradu, Komunisti neće izbeći odmazdi - bili su novinski naslovi koji izveštavaju da je okupator u znak odmazde za napade na njegove zvaničnike streljao veliki broj uhapšenih Jevreja i komunista. ${ }^{36}$ Komandant SS i policije general Avgust Majsner je u razgovoru sa bugarskim generalom za vezu Stančevom nagovestio da će se sa ovom praksom nastaviti i u $1942 .^{37}$

U drugu grupu možemo svrstati preventivne ili zaštitne mere. Odmah po uspostavljanju okupacionog aparata nacisti su radi lakše kontrole zaposednute teritorije doneli niz naredbi. Beograđanima je bilo zabranjeno: kretanje posle 19 časova, okupljanje na ulicama, održavanje bilo kakvih manifestacija, posedovanje vatrenog oružja itd. ${ }^{38}$ Mere koje su okupator i kolaboracionisti koristili u nameri da spreče izvođenje oružanih akcija najvidljivije su u Naredbi 25, koju je 2. novembra 1941. donelo Ministarstvo unutrašnjih poslova vlade Milana Nedića. U njoj je od policijskih organa traženo da se: vrši permanentna kontrola svih putnika koji dolaze u Beograd; osmatraju sumnjiva lica kao i mesta "gde bi se mogao postaviti eksploziv ili proizvesti kakvo delo sabotaže" i „oko stanova visokih funkcionera i uglednih ličnosti koje bi mogle biti predmet kakvog napada“; kvartovske vlasti raspituju o „ispravnosti ljudi koja stanuju u tom rejonu; „održava veze sa državnim i samoupravnim organima, nadzornicima kuća, kafedžijama i kelnerima, uličnim prodavcima“ i drugim „podesnim osobama“ preko kojih bi se prikupljali podaci; u slučaju izvođenja „akta sabotaže ili atentata" svi organi policije najhitnije dođu na radna mesta, obustave ukrcavanje putnika u vozove i parobrode i zatvore ostale izlaze iz Beograda. ${ }^{39}$

${ }^{36}$ Novo vreme, br. 62,18 . jul 1941, 1; Novo vreme, br. 90, 17. avgust 1941, 1; Novo vreme, br. 151, 28. oktobar 1941, 1.

${ }^{37}$ Venceslav Glišić, Teror i zločini nacističke Nemačke u Srbiji 1941-1944, Beograd $1970,72$.

${ }^{38}$ Zbirka naredaba i uputstava, izdanje Opštine grada Beograda, Beograd 1941.

${ }^{39}$ Vojni arhiv (VA), Nedićeva arhiva (NdA) k. 57, f. 1, d. 53, 9. 


\section{Akcije}

Pod uticajem Nemaca ruski emigranti formirali su 1941. godine Ruski zaštitni korpus koji je korišćen za zaštitu privrednih objekata i borbu protiv partizana. ${ }^{40}$ Pripadnici korpusa činili su još jednu potencijalnu metu za komuniste u Beogradu. Prvi napad izvršen na jednog „ruskog dobrovoljca" zabeležen je 1. januara 1942. Na udaru se našao Mstislav Barbović, redov I čete II puka. Barbović opisuje šta se odigralo na taj dan: „Danas oko 9,25 časova, prolazeći Krajinskom ulicom ispred kuće br. 48-50, bio sam zaustavljen s leđa od strane dva mladića, koji su mi naredili da dignem ruke $\mathrm{u}$ vis. Kako sam nosio jedno koferče ja sam isto uradio i okrenuvši se za 180 stepeni, ugledao sam dva mladića, od kojih je jedan naperio revolver $u$ mene. Prilikom ovog pokreta ja sam mahinalno udario dečka po ruci, koji je držao revolver i on je u tom trenutku ispalio hitac." Napadači su krenuli da se povlače, na šta je Barbović izvukao svoje oružje i zapucao u njihovom pravcu ali bezuspešno, uspeli su da pobegnu. Barbović je pred istražnim organima IV odseka Odeljenja specijalne policije opisao ove mladiće: „Napadač koji je držao revolver i pucao izgleda ovako: star oko 20 godina, mislim da je bio plav. Na sebi je imao crni kaput i crni šešir. Mlađi napadač star oko 15-16 g. imao je grao kaput športske grao ili braon pantalone." 41

Nije bilo bezbedno šetati tih dana beogradskim ulicama ukoliko ste pripadnik Ruskog zaštitnog korpusa. Novi napad odigrao se 5 . januara. Organi Specijalne policije na taj dan izvešteni su telefonskim putem „da je na uglu Janka Veselinovića i Prestolonaslednika Petra ulice pucano na nekog dobrovoljca koji je teže ranjen." Izašavši na mesto događaja, dežurni činovnici ovog odeljenja utvrdili su da je „u Prestolonaslednika Petra ulici br. 40, pred drvarom Radaković ubijen obveznik Ruskog korpusa Aleksandar Nestorenko, koji je u uniformi Ruskog korpusa išao u društvu Ane Abramove, učenice zanatske škole, od Čuburskog potoka u pravcu Čubure."

Uz pomoć svedoka, policija je uspela da rekonstruiše događaj i da utvrdi da se ubistvo odigralo sledećim tokom: „Kada su došli do broja 40 Prestolonaslednika Petra (misli se na Nestorenka i Abramovu - R. R.), njima su u susret od Čubure ka Čuburskom potoku naišla dva mladića stara oko dvadeset godina. Jedan od njih, koji je bio srednjeg rasta, star oko 20 godina, plav, kose plave natrag začešljane, gologlav, brade i brkova obrijanih, obučen u dugi zimski kaput liht braon-kao čokolada, stao je pred poč. Nestorenkom i ispruživši ruku prema njegovom nosu rekao mu je: „Šta je ti usranko, šta ti hoćeš." Na ovo izazivanje poč. Nestorenko mu je odgovorio

${ }^{40}$ Aleksej Timofejev, Rusi i Drugi svetski rat u Jugoslaviji: uticaj SSSR-a i ruskih emigranata na događaje u Jugoslaviji 1941-1945, Beograd 2011, 47.

${ }^{41}$ IAB, UGB, SP, IV-109. 
da on neće ništa, već on nešto želi kad ga tako izaziva. Ne odgovorivši ništa, ovaj mladić je trgao iz desnog džepa zimskog kaputa revolver 6.35 i opalio u pravcu Nestorenka." ${ }^{42}$

Napadači su po izvršenom delu počeli da beže niz istu ulicu, odakle su skrenuli u Grahovsku, pa zatim u generala Horvatovića ulicu, uputivši se u pravcu Marinkove Bare. U trenutku napada, na ulicama je bilo „puno sveta" pa su neki od prolaznika pokušavali da uhvate napadače, ali bezuspešno. Teško ranjeni Nestorenko odmah je prenesen u doktorsku ordinaciju koja se nalazila u neposrednoj blizini mesta događaja. Doktor nije mogao da spase život ovom dvadesetogodišnjem gimnazijalcu, metak ga je pogodio „pravo u krvni sud od čega je nastupio izliv krvi u pluća“". ${ }^{43}$

Policiji je trebalo dva dana da identifikuje napadače i uhapsi ih. Ubistvo je izvršio skojevac Dragan Rodić, član udarne grupe na čijem čelu se nalazio član partije Obrad Pelemiš. ${ }^{44}$ Kao motiv za ubistvo Nestorenka, ovaj skojevac je naveo da mu je Pelemiš rekao: „Rusi su isto što i Hrvati i da bi trebalo da se primim toga, da ubijem Ruse-dobrovoljce, koje bi u putu sreo." Kao Rodićevi saučesnici, uhapšeni su studenti Momčilo Mitrović i Mihajlo Anđelković. Hapšenja su omogućila organima IV odseka Odeljenja Specijalne policije da razotkriju ceo ovaj aktiv. Uhapšen je i Pelemiš, kod koga je policija pronašla tri neispravna revolvera. ${ }^{45}$ Kod Rodića je pronađena lažna lična karta na ime Ljubomira Kovačević, što je policiju dovelo do Julijane Nešić, dnevničara zvaničnika UGB, koja je komunistima obezbeđivala lažne isprave. ${ }^{46}$ Iz ove grupe upućeno je u logor Banjica 19 lica. ${ }^{47}$ Rodić je obešen u dvorištu logora na Banjici 14. januara 1942, a na isti dan streljani su i Mitrović i Anđelković. ${ }^{48}$

Povodom ovog slučaja, Novo vreme je 16. januara prenelo „Saopštenje sa nadležnog mesta“: „5 januara 1942. godine Dragan Rodić, učenik VI razreda gimnazije, rođen 6-VIII-1924. god. u selu Trubaru, mučki je ubio Aleksandra Nestorenka, pripadnika Ruskog zaštitnog odreda generalnog opunomoćenika za privredu u Srbiji. Atentator je uhvaćen uz pripomoć srp-

${ }^{42}$ Isto.
${ }^{43}$ Isto.

${ }^{44}$ Dragan Rodić je rođen 6. avgusta 1924. u selu Trubaru, srez Bosansko Grahovo. Nije služio vojni rok. Pobegao je iz Trubara u okupiranu Srbiju pred ustašama. U Beogradu je krenuo u šesti razred I muške gimnazije gde ga je Maksim Krnjačec, takođe učenik ove gimnazije, upoznao sa komunističkom ideologijom. Krnjačec je Rodića predao Pelemišu, koji je radio na ideološkoj izgradnji ovog mladića i učio ga kako da rukuje oružjem. - IAB, UGB, SP, IV-109.

${ }^{45}$ IAB, UGB, SP, IV-109/10.

${ }^{46}$ IAB, UGB, SP, IV-109/13.

${ }^{47}$ IAB, UGB, SP, IV-109.

${ }^{48}$ Logor Banjica: logoraši: knjige zatočenika koncentracionog logora Beograd-Banjica (1941-1944), priredile Evica Micković, Milena Radojčić, tom I, 298. 
ske policije. Pošto je Rodić digao ruku protiv pripadnika Ruskog zaštitnog odreda, koji stoji pod komandom nemačke oružane sile, odmazda za ovaj zločin bila je ista kao da je izvršena protiv nemačkog vojnika. Atentator je obešen 14. januara 1942. godine." U daljem delu saopštenja se upozorava da će "svaki onaj koji bude dizao ruku protiv nemačke oružane sile i vojnika koji se bore u njenim redovima biti nemilosrdno kažnjen. Ni njegovi saučesnici, kao ni oni koji za njegov zločin znaju, a ne dostavljaju vlastima, ne treba da se nadaju milosti." ${ }^{49}$ Potrebno je na ovom mestu naglasiti da nalog za ubistvo Nestorenka nije potekao od MK KPJ i da je ovaj organ na jednom od sastanaka ocenio kako je ovaj akt „neozbiljan, nepotreban i štetan uopšte." ${ }^{50}$

U oktobru 1941. uhapšena je u Kragujevcu Ivanka Muačević Nikoliš, kurir MK za Beograd. ${ }^{51}$ Muačevićeva je od strane Gestapoa upućena u logor na Banjici 12. novembra, odakle je zbog trudnoće premeštena u vojnu bolnicu 28. decembra. ${ }^{52} \mathrm{MK}$ KPJ je doneo odluku da se organizuje njeno bekstvo. Iz vojne bolnice premeštena je pred sam porođaj 20. januara 1942, „usled pomanjkanja stručnog osoblja i drugih potreba“, bez znanja Odeljenja specijalne policije, u slabije čuvano ginekološko odeljenje Opšte bolnice.

Organizacija otmice poverena je Stevanu Jovičiću, članu MK, koji je držao na vezi partijsku jedinicu na čijoj teritoriji se nalazila bolnica. KPJ je imala i jedan aktiv u samoj bolnici koji je u jednom periodu držala Muačevićeva, a preko koga je sakupljan novac za NOF i nabavljan sanitetski materijal. Članovi ovog aktiva doktori Todor Borocki, Olga Dedijer, Nada Petrović, Katarina Marjanović i Anđelko Anđelković, bili su zaduženi da pomognu otmicu iznutra. Plan je bio da trojica ilegalaca uđu u bolnicu, izvedu zatvorenicu i pomognu joj da sa detetom uđe u kamion, dok ostali štite odstupnicu. Zadatak medicinskog osoblja bio je sledeći: Anđelković je trebalo da stoji na ulaznoj kapiji i da signalizira vozaču da li je ulaz u bolnicu slobodan, Marjanovićeva je bila zadužena da u slučaju neke opasnosti na samom odeljenju izađe napolje i o tome izvesti Lazićevu, koja je trebalo da stoji ispred zgrade i da signalizira Anđelkoviću da nije slobodan prolaz, Petrovićeva je trebalo da stoji pred bolničkom sobom uhapšene i dâ znak da je ulaz u sobu slobodan. Zadatak da bude u sobi i pripremi Muačevićevu za bekstvo, imala

${ }^{49}$ Novo vreme, br. 216, 16. januar 1942, 1.

${ }^{50} \mathrm{IAB}, \mathrm{UGB}, \mathrm{SP}, \mathrm{IV}-156 / 6$.

${ }^{51}$ Ivanka Muačević Nikoliš, rođena 11. maja 1911. u Vukovaru. Bila udata za doktora Gojka Nikoliša. Osnovno obrazovanje završila je u Karlovcu i Osijeku. U predratnom periodu hapšena zbog komunističke delatnosti. U prvim mesecima okupacije igra aktivnu ulogu u beogradskoj organizaciji (član je studentskog aktiva, drži ilegalne kurseve prve pomoći, radi kao kurir). Posle otmice iz bolnice upućena na rad u Zagreb gde je otkrivena i streljana u leto 1942. - Žene u NOB, Beograd 1975, 137.

${ }^{52}$ Logor Banjica: logoraši..., tom I, 134. 
je Dedijerova. ${ }^{53}$ U neposrednom izvršenju akcije, osim njih, učestvovali su i sledeći komunisti: Ivan Lenardić, Vojislav Popović, Karlo Lukač, Milić Martinović, Sava Milić, Branko Bulat, Rajko Vićentijević, Branko Sekulić i Nikola Strinek. ${ }^{54}$

Muačevićeva se porodila 21. januara, čime se stekao glavni preduslov za izvršenje akcije. Odlučeno je da se otmica izvrši u nedelju, 25. januara, u vreme kada je dozvoljena poseta bolesnicima. Oko 16 časova, trojica ilegalaca ulaze na ginekološko odeljenje, dok su ostali stajali naoružani oko bolnice. Kako se dalje odvijala akcija, svedoči policijski izveštaj: „Jednog momenta tri naoružana čoveka prišla su stražaru (Stevanu Đuriću, stražarskom pripravniku - R. R.), ovome oduzeli pušku izvadili revolvere uperivši cevi ovome u slepoočnicu sa naređenjem da digne ruke $u$ vis i da ćuti. Isto tako naredili su i svom osoblju bolnice koje se tu zateklo da ćuti i da svaki ostane na mestu gde se zatekao. Jedan od trojice napadača upao je u sobu gde je ležala Ivanka i upitao: 'Ko je ovde Ivanka?' Kada se ova javila on ju je odmah pozvao da pođe sa njim što je ova i učinila odnevši i dete sa sobom. Dvojica od napadača su otišla sa imenovanom niz stepenice, a treći je sa uperenim revolverom na stražara i službenike bolnice kao i ostale, čekao dok su se oni prvi udaljili, a zatim i on iz zgrade pobegao. ${ }^{\text {"55 }}$ Muačevićeva je ušla u kamion, a zatim je smeštena u jedan stan u Cvijićevoj ulici. Policija je blokirala ceo kvart u kome se nalazila bolnica, ali niko nije uhvaćen.

Odeljenje Specijalne policije je odmah sutradan pokrenulo opsežnu istragu koja je trajala sve do jeseni 1942. Ispitivani su svi zaposleni na ginekološkom odeljenju. Organi IV odseka uspeli su da otkriju i uhapse većinu članova bolničkog aktiva. Uhapšeno je oko 30 ljudi, od kojih je 12 upućeno u logor na Banjicu. ${ }^{56}$ Među uhapšenima našli su se otac, sestra i brat Ivanke Muačević. ${ }^{57}$

Osim imena zvaničnika koji su bili u samom vrhu kolaboracionističkog režima kao što su Dimitrije Ljotić, Milan Aćimović, Svetozar Vujković, Dragi Jovanović i drugi, u proglasima KPJ pojavljivalo se i ime Đorđa Kosmajca. ${ }^{58}$ Ovu „počast" podnazornik policijskih agenata X grupe UGB

\footnotetext{
${ }^{53}$ IAB, UGB, SP, IV-201/11.

${ }^{54}$ IAB, UGB, SP, IV-201/28-A.

${ }^{55}$ IAB, UGB, SP, IV-201/29.

${ }^{56}$ IAB, UGB, SP, IV-201/28-A.

${ }^{57}$ IAB, UGB, SP, IV-201.
}

${ }^{58}$ Đorđe Kosmajac, rođen 6. maja 1903. u Vlasenici, Bosna i Hercegovina. Završio je tečaj policijskih agenata u Zemunu. Od 1926. na radu u UGB. U predratnom periodu radio u IV odseku Odeljenja specijalne policije i učestvovao u mnogim istragama i hapšenjima komunista. Bio je aktivan u pokretu Zbor. Po okupaciji vratio se na posao u UGB. Na isleđenju pred organima OZNE Božidar Bećarević je označio Kosmajca kao jednog od agena- 
Kosmajac je zaslužio dugogodišnjim radom na suzbijanju komunističke delatnosti u predratnom periodu. Kosmajac je nastavio da radi na ovom polju i po dolasku okupatora. Bio je deo ekipe agenata koji su kružili ulicama Beograda u potrazi za komunistima. Po osnivanju koncentracionog logora na Banjici, postaljen je za zamenika upravnika. ${ }^{59}$

Krajem februara 1942, Jelena Ćetković je na jednom od sastanaka ovog foruma izvestila ostale članove MK KPJ kako je dobila naređenje od OK KPJ da se Kosmajac likvidira. Đetkovićeva je na ovom sastanku dala nalog da se „ustanovi gde stanuje, kuda se i kako kreće i kako je najzgodnije izvršiti atentat". Organizaciju atentata poverila je Petru Ristiću. On je od sekretara, Milovana Stefanovića i Aleksić Save, člana III rejonskog aktiva „zatražio potrebne ljude za atentat i dao potrebne instrukcije“. ${ }^{60}$ Oni su Ristiću „stavili na raspoloženje“ Milića Martinovića i Branka Bulata. Ekipu za likvidaciju Kosmajca kompletirao je Martinović, angažujući Đuru Mađerčića i Nikolu Strineka. ${ }^{61}$

Deo naoružanja za akciju obezbeđen je iz „arsenala“ sakrivenog $\mathrm{u}$ zgradi na Zelenom vencu br. 4. Po nalogu Stefanovića ovo oružje je preuzeo iz skloništa Dragan Aleksić. Kako je izvršio zadatak Aleksić je opisao na sledeći način: „Oko 10 časova otišao sam u pomenutu stolarsku radionicu (skrovište naoružanja na Zelenom vencu - R. R.). Tamo sam zatekao samo jedno lice. Ovome sam se obratio sa lozinkom: „Poslala me tetka Persa za pekmez“. Kad je ovaj to čuo, on mi je dao jednu pripremljenu korpu u kojoj su odozgo bila naslagana iscepana drva. Sa ovom korpom sam se ja uputio ulicom Kraljice Natalije, gde me je čekao Stefanović. Njemu sam predao korpu sa oružjem. Šta je on dalje uradio sa tim oružjem meni nije pozna-

ta koji su prilikom ispitivanja uhapšenih primenjivali silu. - VA, Nda, k. 133, f. 1, d. 11; IAB, istražni predmet Božidara Bećarevića.

${ }^{59}$ Branislav Božović, Beograd pod komesarskom upravom 1941 godine, Beograd 1998, 194.

${ }^{60} \mathrm{IAB}, \mathrm{UGB}, \mathrm{SP}, \mathrm{IV}-73 / 96$.

${ }^{61}$ Đuro Mađerčić, rođen 9. aprila 1922. u Živkovića Kosi, Hrvatska. Po zanimanju je bio bravarski radnik, nije služio vojsku. U komunističkom pokretu aktivan i u predratnom periodu, a član KPJ postao je u oktobru 1941. Milić Martinović je rođen 2. oktobra 1917. u Krtinji kod Vojnića, Hrvatska. Kao i Mađerčić i Milić je dolazio iz redova radnika, ali je za razliku od svog ideološkog istomišljenika odslužio vojni rok kao redov. Primljen je u KPJ avgusta ili septembra 1941. Obojica su bili članovi partijskog aktiva na teritoriji III rejona. Od jeseni 1941. Mađerčić i Milić postali su članovi udarne grupe. Prema sopstvenom priznanju zajedno su učestvovali u pokušaju atentata na kafedžiju Rada Ponorca i uglednog funkcionera Zbora dr Velimira Danilovića. Mađerčić nije bio vešt atentator. Prilikom napada na Ponorca nije uspeo ni da puca, a u pokušaja atentata na Danilovića pucajući nekoliko puta iz neposredne blizine uspeo je da mu nanese samo lakše povrede. Poslednja akcija koju su izveli ova dvojica bio je atentat na Đorđa Kosmajca u martu 1942, a ubrzo potom su uhapšeni i upućeni na Banjicu. Izvedeni su iz logora 11. avgusta 1942. i streljani. - IAB, UGB, SP, IV156/32; IAB, UGB, SP, IV-156/34; Logor Banjica: logoraši..., tom I, 401. 
to. “62 Stefanović je predao Martinoviću dva revolvera i četiri bombe. Druga dva revolvera obezbedio je Petar Gvojić, sekretar VII rejonskog aktiva, a predata su takođe Martinoviću od strane neimenovane devojke. ${ }^{63}$

Atentatori su se našli 6. marta oko 7 sati i 20 minuta u ulici Draže Pavlovića, gde im je Martinović predao revolver sa punim šaržerom i po jednu bombu. Dogovor je bio da se iz ove ulice upute u ulicu Zmaja od Noćaja gde je, prema informacijama koje su imali, trebalo da prođe Kosmajac. ${ }^{64}$ Oko 8 časova ujutru napadači su došli u ulicu Zmaja od Noćaja i rasporedili se: Strinek je stajao na uglu ulica Zmaja od Noćaja i Kralja Petra, Mađerčić u jednoj kapiji blizu ulice Cara Uroša, Bulat i Milić sakrili su se u drugu kapiju blizu ulice Kralja Petra. ${ }^{65}$

Kosmajac je u pratnji policijskog agenta UGB Obrada Zalada ${ }^{66}$ oko 8 časova ušao u deo ulice Zmaja od Noćaja gde su ga čekali atentatori, a šta se dalje odigralo saznajemo iz iskaza Mađerčića: „Kada su naišli Kosmajac i Zalad prošli su pored mene, pa onda i pored Martinovića i Bulata. Kada su prošli njih dvojcu, mi smo izišli iz kapije i pripucali na njih u leđa. Kosmajac je se odmah srušio, a Martinović i Bulat su pobegli natrag ka Kalemegdanu. Zalad je međutim pripucao i otrčao ka Kralja Petra ulici. Ja sam pak prišao Kosmajcu, koji je ležao na trotoaru i ispalio jedan metak u njega (Mađerčić je ovaj metak ispalio Kosmajcu u usta - R. R.), pa sam odmah utekao za Martinovićem i Bulatom ka Kalemegdanu. " ${ }^{67}$ Revolverske hice čuli su gestapovac Jakob Novak i folksdojčer Bezimer Fridrih i odmah krenuli ka ulici Kralja Petra. U ovoj ulici sreli su Zalada kako trči ka njima sa pištoljem u ruci. U „uverenju da pred sobom ima zločinca“ Novak je „opalio dva puta iz revolvera, no da li je pogodio ovo lice, za koje veli da je se srušilo na kolodvoru - sredini Kralja Petra ulice, to pozitivno ne zna." ${ }^{\text {"68 }}$ Nemci

\footnotetext{
${ }^{62} \mathrm{IAB}, \mathrm{UGB}, \mathrm{SP}, \mathrm{IV}-73 / 4$.

${ }^{63}$ IAB, UGB, SP, IV-156/32.

${ }^{64}$ IAB, UGB, SP, IV-156/31.

${ }^{65}$ IAB, UGB, SP, IV-156/34.
}

${ }^{66}$ Obrad Zalad, rođen 23. oktobra 1911. u selu Isaković, srez Glamočki, Bosna i Hercegovina. Od školske spreme imao je četiri razreda osnovne i četiri razreda građanske škole. Pre stupanja u državnu službu bio je privatni činovnik. U policiju dolazi 28. aprila 1936. Odlikovan 1938. Srebrnom medaljom za usluge Kraljevskom domu. Radio u zagrebačkoj policiji u policijskoj straži, a zatim od 26. maja 1940. u Odeljenju opšte policije UGB. Okupacija ga zatiče neoženjenog, sa zvanjem agenta pripravnika. Zalad je, kao i mnogi policijski službenici UGB, otpušten zbog prekobrojnosti iz službe 5. juna 1941. U zbor policijskih agenata UGB vratio se samo mesec dana kasnije. - IAB - UGB OPA, inv br. 18/3-1.

${ }^{67}$ IAB, UGB, SP, IV-156/34.

${ }^{68}$ Ostaje nepoznanica ko je ubio Zalada. Treba napomenuti da su svedoci izjavili kako su ubrzo posle prve serije pucnjeva čuli i druge, da je citirana izjava Novaka jedina koju je dao o ovom slučaju i da se on osim nje ne spominje više u kolaboracionističkim i okupacionim izvorima. - IAB, UGB, SP, IV-156/68. 
su zatim krenuli u poteru za napadačima ali bezuspešno. Pobegavši na obalu Dunava, gde su kod fudbalskog igrališta „Jedinstvo“ sakrili oružje, Bulat, Mađerčić i Strinek su se izgubili u nepoznatom pravcu, dok je Martinović otišao u Hadži Prodanovu ulicu da o rezultatima izvesti Ristića. ${ }^{69}$

Kolaboracionistički organi su izašli na lice mesta i napravili blokadu. Sedam patrola sa po dvoje ljudi poslato je u pravcu Dunava i Kalemegdana „radi hvatanja sumnjivih lica i drugih koji bi mogli doći u obzir za izvršena ubistva." U ulici Zmaja od Noćaja policija je zatekla užasan prizor: Kosmajac je ležao mrtav, sa ranom u predelu srca i velikom rupom na glavi, dok je krv tekla niz slivnik sve do ugla ulice Kralja Petra. Zalad je ležao pogođen u grudi i stomak u ulici Kralja Petra i davao znake života. Prenesen je u Opštu bolni$\mathrm{cu}$, gde je od posledica povreda preminuo. ${ }^{70}$

Sahrani Kosmajca i Zalada prisustvovali su Dragi Jovanović, Dimitrije Ljotić, Mihajlo Olćan i drugi kolaboracionistički zvaničnici. Posle pomena pred kapelom Jovanović je „uzbuđenim glasom“ održao govor, u kome se obratio građanima: „Beograde! Još jedna za drugom padaju glave tvojih sinova, padaju onako kako ne dolikuje Srbima, ljudima, Hrišćanima da se ubijaju. Padaju službenici jednog naroda koji su u najtežem momentu stali na branik da odbrane od nekrsta i od neljuda. Oni su doneli odluku da treba ubiti nekolicinu funkcionera nabrojanih u spisku Komunističke partijske organizacije, da bi razorilo ono što je počelo da se kristalizira: sreća i budućnost srpskog naroda." Jovanović dalje upozorava: „Čaša gorčine je puna i prepuna! Nećemo moći da se suzdržimo prema ubicama i svima onima koji kao ubice misle.“" ${ }^{\text {"1 }}$ Okupator se „potrudio“ da Jovanovićeve pretnje ne ostanu prazna priča. Po naredbi Majsnera, kao mera odmazde zbog ubistva Zalada, Kosmajca i policijskog činovnika iz Pančeva Aloja Krala, streljano je 7. marta 150 „beogradskih i pančevačkih komunista“.72

Sledeća glava koja je „pala“ bila je starešine I kvarta UGB, Dragoljuba Šterića. Kao i u slučaju Kosmajca, organizacija ovog atentata poverena je III partijskom rejonu. Inicijator akcije bio je Karlo Lukač, ${ }^{73}$ sekretar jednog od partijskih aktiva na ovom rejonu, a u njoj su učestvovali Sava Milić i Predrag Vijorović. Oružje koje je korišćeno za likvidaciju Kosmajca upotrebljeno je i ovaj put. Milić Martinović ga je po nalogu Save Aleksića predao

\footnotetext{
${ }^{69} \mathrm{IAB}, \mathrm{UGB}, \mathrm{SP}, \mathrm{IV}-73 / 96$.

${ }^{70}$ IAB, UGB, SP, IV-156/69.

${ }^{71}$ Novo vreme, br. 261, 8. mart 1942, 3.

72 Isto.
}

${ }^{73}$ Karlo Lukač, rođen 9. maja 1914. u Titelu. Po zanimanju je bio konobar. Radio je u beogradskim ugostiteljskim objektima, a poslednje radno mesto bilo mu je u kafani „Ginić“. U KPJ je bio aktivan i u predratnom periodu; bio je predsednik udruženja ugostiteljskih nameštenika. Hapšen je zbog komunističke delatnosti 1940. godine. - IAB, UGB, SP, IV-156/70; IAB, UGB, SP, IV-156/43. 
Lukaču i Miliću. $^{74}$ Za neposrednog izvršioca atentata određen je Lukač, dok su Milić i Vijorović imali zadatak da štite odstupnicu.

U subotu 14. marta, oko 7 časova, sakupili su se Lukač, Vijorović i Milić na Zelenom vencu i uputili se ka zgradi u ulici Kneza Pavla 47 gde je stanovao Šterić. Oko 7,50 našli su se ispred Šterićevog ulaza. Vijorović je zauzeo položaj ispred kapije ovog ulaza, a Milić je stajao na ulici. Lukač je ušao u ulaz i našao idealno mesto za zasedu - jedan ugao slabo osvetljenog hodnika, kod vrata koja vode u podrumske prostorije, odakle je mogao da motri na sve one koji silaze niz stepenice, a da ostane neprimećen. Nedugo zatim nailazi Šterić koji je krenuo na posao, Lukač mu prilazi i iz neposredne blizine ispaljuje u njega tri metka. Pogođen u glavu i grudi, Šterić je kratko davao znake života da bi ubrzo zatim preminuo. ${ }^{75}$

Pucnjavu je čuo Đorđe Conić, policijski agent UGB, koji se nalazio u blizini Šterićevog ulaza. Ovaj agent se okrenuo i primetio Lukača kako „gura veliki revolver u džep od kaputa." Conić je potrčao za atentatorom i dozvao još dva slučajna prolaznika, koja su mu se pridružila u poteri. Lukač je pokušao da puca na njih, ali mu se zaglavio metak u cevi. Jurnjava je nastavljena Carigradskom ulicom, a odatle Budimskom gde je naišao ,jedan autobus srpskih oružanih odreda“. Conić je pozvao šofera (po činu narednik) i njegovog pomoćnika da uhvate Lukača. Šofer je otvorio vatru na Lukača, ali ga nije pogodio, „te je begunac skrenuo ka Takovskoj ulici ulicom Kneza Pavla“. U ovoj ulici, poteri su se pridružila „još dva vojnika iz Gestapo-a od kojih je jedan pokušao da puca ali mu se metak zaglavio.“ Opet je počeo da puca šofer autobusa i uspeo da pogodi Lukača, koji je uprkos ovome nastavio da beži. Narednik je predao pušku svom pomoćniku „koji ju je napunio, klekao i ispalio za ovim pet metaka, kada je zašao u Takovsku ul. pogodio ga i na mestu ubio“. Policija je kod Lukača pronašla pištolj marke mauzer, zarđalu defanzivnu bombu domaće proizvodnje i dozvolu za noćno kretanje. Milić i Vijorović su uspeli da pobegnu. ${ }^{76}$

Premda je Šterić likvidiran, akcija je predstavljala potpun neuspeh jer je Lukač ubio pogrešnog čoveka. Na meti je trebalo da se nađe Stevan Šterić, jedan od službenika IV odseka Odeljenja specijalne policije, poznatih po primeni brutalnosti prema uhapšenicima, a ne njegov brat Dragoljub koji je, prema svemu sudeći, sarađivao sa pojedinim komunistima izdavajući im propusnice za „izlazak iz blokiranog Beograda“ ${ }^{77}$

Kako su pojedini Beograđani videli ovaj događaj saznajemo iz dnevnika Dragutina J. Ranković: „Jutros je ubijen Dragoljub Šterić, član I kvar-

\footnotetext{
${ }^{74} \mathrm{IAB}, \mathrm{UGB}, \mathrm{SP}, \mathrm{IV}-156 / 31$.

${ }^{75}$ IAB, UGB, SP, IV-156/47.

${ }^{76}$ Isto.

${ }^{77} \mathrm{IAB}, \mathrm{K}-\mathrm{II}-535$
} 
ta. Pok. Šterić je bio istinski dobar čovek i dobar policajac. Otuda je svima čudo zašto je atentator baš njega izabrao za svoju žrtvu. O ubici se razno govori. Neki kažu da je Hrvat - ustaša, drugi da je komunista. Bilo ma kako, za žaljenje je što je Šterić izgubio život. Dobro je što ga nije ubio Srbin, premda i mi Srbi pravimo gluposti i zbog jednog ubijenog stotine plaćaju svojim glavama. Zar nas ima toliko mnogo pa se možemo sami istrebljivati?" 78

Ubistvo Šterića je bila poslednja akcija izvedena protiv okupatora i kolaboracionista u 1942. Učestala hapšenja primorala su KPJ na „povlačenje“. Prvo veće hapšenje izvršeno je 8 . januara kada je Odeljenje specijalne policije privelo na jednom „žuru“ 35 skojevaca. U ovom periodu uhapšena je i grupa povezana sa atentatorom Draganom Rodićem. U januaru je nastavljeno sa hapšenjem skojevaca - $u$ drugoj polovini meseca privedeno je 17 lica iz skojevskog aktiva na Dedinju. Provala u skojevskoj organizaciji zaokružena je u februaru, kada je policija uhapsila sve članove MK SKOJ-a za Beograd, osim sekretara Bore Drenovca. Najžešći udar došao je u martu. Trećeg marta uhapšeni su Jelena Ćetković, sekretar MK KPJ za Beograd i Marko Janković, sekretar IV partijskog rejona. Devetog marta uhapšen je član MK Petar Ristić, uz pomoć koga je policija došla do podataka o komunistima iz III, IV, VI, a delom i V i VII rejona. Prema podacima Odeljenja specijalne policije, samo u ovoj provali uhapšeno je 86 lica, a ukupno za prva tri meseca 1942. godine lišeno je slobode 158 ljudi. Među uhapšenima se našao veliki broj rukovodećih kadrova, što ovu provalu čini najrazornijom. Od njenih posledica organizacija KPJ u Beogradu se do kraja Drugog svetskog rata nije oporavila. ${ }^{79}$ I članovi OK našli su se na udaru Odeljenja specijalne policije. Početkom aprila ubijen je sekretar OK Todor Dukin, a ubrzo zatim istu sudbinu doživeo je i organizacioni sekretar OK Mija Kovačević.

Do konsolidacije u redovima beogradske organizacije dolazi krajem jula i početkom avgusta, kada je ponovo obrazovan MK KPJ. Za sekretara je postavljen Janko Lisjak zvani Puška, a ostali članovi bili su Đurđelina Dinić i Razumenka Petrović. Teritorija UGB je podeljena na četiri rejona, umesto nekadašnjih sedam, u kojima su postavljena i rukovodstva. ${ }^{80}$

Novi MK je radio i na obrazovanju udarnih grupa, sa ciljem da se opet počne sa likvidacijama. Policijski organi su zabeležili samo jednu akciju takvog karaktera u ovom periodu. U septembru je doneta odluka da se

${ }^{78}$ Svakodnevni život pod okupacijom 1941-1944: iskustvo jednog Beograđanina, priredili Nataša Milićević, Dušan Nikodijević, Beograd 2011, 175.

${ }^{79}$ B. Božović, Specijalna policija u Beogradu 1941-1944, 157.

NOP-a..., 28.

${ }^{80}$ Đurđević Čedomir, Komunistička partija Jugoslavije - organizator i nosilac 
ubije Jelena Matić, bivši član KPJ. Matićeva je uhapšena jula 1941. u Čačku, gde je bila član OK KPJ za Čačanski okrug i upućena u logor na Banjici. Posle pet meseci provedenih u logoru, Matićeva je puštena. ${ }^{81}$ Njeno puštanje na slobodu iskoristili su pripadnici kvislinške organizacije Zbor, kao argument da UGB ne radi svoj posao kako treba. ${ }^{82}$ Posmatrano iz kvislinškog ugla $u$ jednom delu tvrdnje pripadnici Zbora bili su u pravu: puštanje Matićeve, s obzirom na položaj koji je zauzimala u KPJ, bila je protekcija, ali protekcija koja nije došla kao plod korupcije u redovima UGB nego taktike da se pogodni uhapšeni komunisti zavrbuju i postanu saradnici Odeljenja specijalne policije. ${ }^{83}$ Kada se našla na slobodi, Matićeva je počela da „služi Antikomunističkom odseku Specijalne policije kao poverenik protiv komunista". ${ }^{84}$

Organizacija atentata poverena je II partijskom rejonu. Članovi ovog rejona Ratomir Đelmaš i Radivoje Božović angažovali su udarnu grupu na čijem čelu se nalazio izvesni „Plavi“. Za samo izvršenje ubistva određen je Ilija Mrgić. ${ }^{85}$ „Plavi“ je 15. septembra saopštio Mrgiću „da je pala odluka da se likvidira" Matićeva i 17. septembra mu predao „jedan vojno državni revolver $9 \mathrm{~mm}$ sa municijom i kamu“. Po predavanju oružja „Plavi“ je održao kratku lekciju Mrgiću iz rukovanja lakim naoružanjem u „javnom klozetu“, koji se nalazio u parku na Vračaru. Istog dana oko 11 časova otišli su u poslastičarnicu na uglu Njegoševe i Jovana Ristića ulice, gde im se pridružilo još dvoje neimenovanih lica, predviđenih da pomognu Mrgiću. Plan je bio da Mrgić sa jednim od ove dvojice, predstavljajući se kao policajac, uđe u stan Matićeve, koji se nalazio u prizemlju zgrade u Ulici Alekse Nenadovića 3, a jedan da ispred zgrade čuva stražu.

Po dogovoru, 18. septembra oko 7 časova Mrgić se našao sa svojim pomagačima i uputio ka stanu Matićeve. Dalji tok dešavanja Mrgić je opisao na sledeći način: „Partizan (za jednog od dvojice pomagača Mrgić je na isleđenju tvrdio da je došao iz partizanskog odreda - R. R.) je pritisnuo na zvono i pošto je Matićeva otvorila vrata saopštili smo joj da smo organi Uprave grada i dolazimo radi pretresa. Pošto nas je Matićeva pustila u stan i mi smo videli u brzini da je sama, partizan joj je priskočio i snažnim pokretom

${ }^{81}$ Logor Banjica: logoraši..., tom I, 68.

${ }^{82}$ VA, Nda, k. 20 A, f. 4, d. 43.

${ }^{83}$ Više o ovoj temi: Branislav Božović, Specijalna policija u Beogradu 1941-1944, 389-393.

${ }^{84}$ IAB, UGB, SP, IV, 202.

${ }^{85}$ Ilija Mrgić, rođen 22. avgusta 1920. u selu Gornje Poloje, Hrvatska. Po zanimanju je bio krznarski radnik. Kao pitomac „Privrednika“ 1935. dolazi u Beograd gde posle četiri godine učenja zanata postaje krznarski pomoćnik. U komunistički pokret uključuje se 1940, a 1941. postaje član partije. U okupaciji radio na terenu II i III partijskog rejona. IAB, UGB, SP, IV, 202; Logor Banjica: logoraši..., tom I, 529. 
je oborio na zemlju. Ja sam već bio spreman te sam otpočeo da joj zadajem udarce kamom pri čemu mi je partizan pomogao." ${ }^{\text {c6 }}$

Uprkos ranama Matićeva uspeva da iskoči kroz prozor na ulicu, Mrgić ispaljuje na nju dva metka i ubija je na ulici. Dok su se još nalazili u stanu, „kukanje napadnute“ alarmiralo je policijskog kaplara Dušana Bursaća. Ovaj kvartovski stražar dao se u poteru koja je, prema njegovim rečima, imala sledeći tok: „Kada sam ja bez oružja jurišao na njega (na Mrgića - R. R.) da ga razoružam i uhapsim okrenuo je na mene revolver te ispalio pet metaka od kojih me ni jedan nije ranio. Videvši da pred sobom imam ubicu i opasno lice po javnu bezbednost dao sam se za istim u poteru, te je ponovo pred kućom broj 14, uperio na mene revolver i ispalio jedan metak, ali neprezajući za svoj život ja sam i dalje za istim jurio uzeo jedan kamen sa ulice udario ga u zatiok-vrata, sustigao ga na uglu Njegoševe i Smiljanićeve tu ga oborio na zemlju i razoružao ga." ${ }^{87}$ Mrgićevi saučesnici su uspeli da pobegnu. O daljoj sudbini ovog 19-godišnjeg krznarskog pomoćnika ostao je kratak zapis u knjizi zatvorenika logora Banjica: „U logoru od 26. X. 1942. od UGB. Streljan 25. I. 1943."

Hvatanje Mrgića je izazvalo novi talas hapšenja. Konfinirano je 71 lice, najveći broj uhapšenih radio je na teritoriji I i II rejonskog komiteta. Sa hapšenjima je nastavljeno u oktobru, ali i sve do oslobođenja Beograda 1944. godine. KPJ u Beogradu nije bila u stanju da ponovo pokrene borbu protiv okupatora i kolaboracionista. Postojali su planovi da se u jesen 1943. ponovo obrazuju udarne grupe i krene sa atentatima, ali oni nisu ostvareni usled provale u oktobru iste godine. ${ }^{88}$

Tokom 1942. godine beogradski ilegalci izveli su četiri atentata od čega su tri bila na zvaničnike kolaboracionističkog režima, a jedan na poverenika policije. Imena Barbovića, Nestorenka, Kosmajca, Zalada i Šterića ne mogu se, po važnosti, svrstati u prvi red kolaboracionističkih zvaničnika, što je znak da su preventivne mere zaštitile čelne ljude ovog režima. Podatak da se nijedan Nemac nije našao na nišanu beogradskih komunista govori da je represivna politika okupatora u 1941. razuverila čelne ljude KPJ u delotvornost akcija ovakve vrste. Spasavanje Ivanke Muačević Nikoliš iz bolnice dobar je primer da je beogradska organizacija uprkos svim hapšenjima u 1941. i dalje imala kadrove sposobne za planiranje i izvođenje kompleksnih zadataka. Pokušaj Ilije Mrgića da Jelenu Matić usred dana u jednom gradu likvidira nožem ruši stereotip da je upotreba hladnog oružja $u$ obračunavanju sa neprijateljima tokom Drugog svetskog rata bila strana pripadnicima ovog antifašističkog pokreta.

\footnotetext{
${ }^{86}$ IAB, UGB, SP, IV, 202.

${ }^{87}$ Isto.

${ }^{88}$ AS, BIA, k. 20.
} 
Rade Ristanović

THE RESISTANCE ACTIONS OF THE COMMUNIST ILLEGALS IN BELGRADE DURING THE YEAR 1942

\section{Summary}

In the beginning of 1942 started the reorganization and foundation of the new City Commitee of the Communist Party in Belgrade. New founded City Commitee, started to implement orders since Septemper 1941, which meant The Communist Party to organize the groups with a mission to assassinate and disarm the officials of the occupier and collaborationists. Since January until September 1942, communists in Belgrade made four assassinations, included three on the officials of collaborationist regime and one on a police officer. Collaborationists, Barbović, Nestorenko, Kosmajac, Zalad and Šterić, could not be counted as the first-line officials, which indicates that preventive measures of high officials protection had been implemented correctly. The fact considering German citizens, soldiers and officials not founded at gunpoint of communists in Belgrade, indicates that repressive politics of occupier, during 1942, undeceived the leaders of the Communist Party in effectiveness of the actions they implemented until recently. Rescuing Ivanka Muačević Nikoliš from the hospital is a good example and a proof for the Communist Party in Belgrade, despite the arrests, to have members, trained to plan and implement the missions so complexed. Attempt of Ilija Mrgić to assassinate Jelena Matić by knife, during the day light, demolishes the stereotype originated from influences of socialist historiography - during the World War II, use of cold weapons was unknown to protectors of the communist ideology. It is noticed, that the Communist Party in Belgrade, after every organized attack on occupier, had come under attack of police force, which resulted with arrests, not only of individuals, but whole groups of them. These events lead us to conclude, that armed struggle under this conditions, was contraproductive. 